\title{
Anti-inflammatory effect of the sclerotium of Lignosus rhinocerotis (Cooke) Ryvarden, the Tiger Milk mushroom
}

\author{
Sook Shien Lee ${ }^{1}$, Nget Hong Tan", Shin Yee Fung ${ }^{*}$, Si Mui Sim², Chon Seng $\operatorname{Tan}^{3}$ and Szu Ting Ng ${ }^{4}$
}

\begin{abstract}
Background: The sclerotium of Lignosus rhinocerotis (Cooke) Ryvarden (Tiger Milk mushroom) is used as a traditional medicine to relieve cough, asthma and chronic hepatitis. The traditional uses of the sclerotium are presumably related to its anti-inflammatory effect. The present study was carried out to evaluate the anti-inflammatory activity of the sclerotial powder of L. rhinocerotis (Cooke) Ryvarden (Tiger Milk mushroom) cultivar TM02.

Methods: The anti-acute inflammatory activity of the sclerotial powder of L. rhinocerotis cultivar TM02 was investigated using carrageenan-induced paw edema test while the inhibition of transudative and proliferative phases of chronic inflammation were studied by cotton pellet induced granuloma model. Sprague Dawley rats were used in both studies. The anti-inflammatory activity was also measured by inhibition of lipopolysaccharide induced TNF-alpha production in RAW 264.7 macrophage cells.

Results: Cold water extract (CWE), hot water extract (HWE) and methanol extract (ME) of the sclerotial powder of L. rhinocerotis cultivar TM02 possessed anti-acute inflammatory activity as was measured by carrageenan-induced paw edema test, with CWE being the most potent. The acute anti-inflammatory activity of the cold water extract (CWE) was mainly contributed by its high molecular weight (HMW) fraction isolated by Sephadex G50 gel filtration chromatography. Its protein component was very potent in the inhibition of TNF-alpha production with an $\mathrm{IC}_{50}$ of $0.76 \mathrm{\mu g} / \mathrm{ml}$. CWE at $200 \mathrm{mg} / \mathrm{kg}$ did not inhibit transudative and proliferative phase of chronic inflammation as shown by using the cotton pellet induced granuloma model.
\end{abstract}

Conclusions: Our results suggested that most of the bioactive substance(s) contributed to the acute-inflammatory activity of the sclerotial powder of L. rhinocerotis cultivar TM02 appear to be in the CWE, particularly its HMW fraction. The anti-inflammatory activity of CWE was mainly contributed by the protein component of the high molecular weight (HMW) fraction and it exhibited strong inhibitory effect on TNF-alpha production but the possibility of synergistic effect between HMW, MMW and LMW fractions cannot be excluded. Future studies will provide new insights into the anti-inflammatory activity of the sclerotial powder.

Keywords: Lignosus rhinocerotis, Sclerotium, Anti-inflammatory, Carrageenan-induced paw edema, Cotton pellet induced granuloma

\footnotetext{
* Correspondence: fungshinyee@gmail.com

'Department of Molecular Medicine, Faculty of Medicine, University of Malaya, 50603 Kuala Lumpur, Malaysia

Full list of author information is available at the end of the article
} 


\section{Background}

Inflammation is a normal protective response to tissue injury caused by physical trauma (cut, burn or bruise), noxious chemicals, microbiologic agents or even autoimmune disease [1]. Excessive inflammation may, however, lead to tissue injury and when severe, cause physiological decompensation, organ dysfunction and death cascade [2].

Non-steroidal anti-inflammatory drugs (NSAIDS) which are effective for the treatment of inflammation are among the most widely used drugs in the world [3]. However, NSAIDs are associated with several side effects, especially gastrointestinal toxicity including ulcerations, erosions, life-threatening perforations or severe hemorrhage [4]. Therefore, there is a need to search for alternative antiinflammatory agent with reduced side effects.

Lignosus rhinocerotis (Cooke) Ryvarden (Tiger Milk mushroom, synonym: Lignosus rhinocerus), is an important medicinal mushroom in Southeast Asia and China. In Malaysia, it is also known as 'cendawan susu rimau' and is the most popular medicinal mushroom used by the indigenous communities of Peninsular Malaysia to relieve fever, cough, asthma, cancer, food poisoning and as a general tonic $[5,6]$. In China, the sclerotium of the mushroom is an expensive traditional medicine used for the treatment of liver cancer, chronic hepatitis and gastric ulcers [7]. The sclerotium of $L$. rhinocerotis is the part with medicinal value. Unfortunately, the existence of this mushroom in the jungle is always solitary and this makes collection of large quantity of the mushroom's sclerotia a difficult task. Recently, Tan [8] reported a successful cultivation of the mushroom in agar, solid and spawn medium with good yield, thus making it possible to fully exploit its medicinal and functional benefits. To date, anti-inflammatory activity of L. rhinocerotis has not been investigated. In the present study, we report the investigation of the in vivo anti-inflammatory activity of the extracts of sclerotial powder of the mushroom using a rat model as well as the in vitro inhibitory activity on lipopolysaccharide induced TNF-alpha production in macrophage cells.

\section{Methods}

\section{Preparation of the sclerotial powder of $L$. rhinocerotis} cultivar TM02

The sclerotia of L. rhinocerotis cultivar TM02 was provided by Ligno Biotech Sdn. Bhd. (Selangor, Malaysia) and were identified by their internal transcribed spacer (ITS) regions of the ribosomal DNA [9]. Sclerotia were freezedried and milled into powder using $0.2 \mathrm{~mm}$ sieve. The powder is light brown, dry fluffy with milk-like taste.

\section{Extraction from the sclerotial powder of L. rhinocerotis cultivar TM02}

Cold water extract (CWE) was prepared by continual stirring of the sclerotial powder for $24 \mathrm{~h}$ in distilled water at $4^{\circ} \mathrm{C}$. The extract was termed CWE TM02. Hot water extraction of the sclerotial powder was performed using an oil bath at $95^{\circ} \mathrm{C}$ to $100^{\circ} \mathrm{C}$ for $2 \mathrm{~h}$. The extract was termed HWE TM02. Methanol extraction was carried out by continual stirring of the powder in methanol at $25^{\circ} \mathrm{C}$ for $24 \mathrm{~h}$. The extract was termed ME TM02. All extractions were performed with sample to solvent ratio of $1 \mathrm{~g}: 20 \mathrm{ml}$. After each extraction, the mixture was centrifuged at $8000 \times \mathrm{g}$ for $30 \mathrm{~min}$. The supernatant was filtered to remove insoluble materials. The aqueous extracts were freeze-dried while the methanol extract of the sclerotial powder was evaporated to dryness using at rotary evaporator at $37^{\circ} \mathrm{C}$.

\section{Determination of total carbohydrate and protein contents of the sclerotial extracts of $L$. rhinocerotis cultivar TM02}

Total protein content was determined according to Bradford method [10]. Bovine serum albumin was used as a standard. Total carbohydrate content was determined by phenol sulphuric acid method according to Dubois et al. [11]. Glucose standard curve was prepared by using $\mathrm{D}$-glucose.

\section{Fractionation of CWE of the sclerotial powder of $L$. rhinocerotis}

CWE TM02 was fractionated using Sephadex G-50 (Sigma-Aldrich, USA) Superfine column (v=112 ml) and eluted with $0.05 \mathrm{M}$ ammonium acetate buffer at $0.5 \mathrm{ml} / \mathrm{min}$. High molecular weight (HMW) fraction appeared at void volume (mol. wt. $>10 \mathrm{kDa}$ dextran or $30 \mathrm{kDa}$ protein) while low molecular weight (LMW) fraction emerged at bed volume. Medium molecular weight (MMW) fraction appeared between void and bed volume. Protein and carbohydrate distribution of each fraction and the pooled fractions (high, medium and low molecular weight fractions) were determined by Bradford and phenol sulphuric acid method, respectively, as described earlier.

\section{Animals}

Six male Sprague Dawley (SD) rats of 9 weeks old (240$270 \mathrm{~g})$ were used for each treatment of carrageenan induced paw edema test while 8 weeks old (170-200 g) were used for cotton pellet induced granuloma test. The animals were supplied by Chenur Supplier (Selangor, Malaysia). The animals were kept under standard conditions (temperature at $22 \pm 2^{\circ} \mathrm{C}, 12 \mathrm{~h}$ light, $12 \mathrm{~h}$ dark), and given food and water ad libitum. Animals were acclimatised before use. The animals were handled according to the CIOMS guidelines [12]. Experimental protocols reported in this study were approved by Institutional Animal Care and Use Committee, University of Malaya (UM IACUC-Ethics reference no. PM/16/11/2010/0812/FSY (R)). 


\section{Carrageenan induced paw edema study}

Carrageenan induced paw edema method was carried out according to Arawwawala et al. [13], with modifications. CWE TM02 (25, 50, 100 or $200 \mathrm{mg} / \mathrm{kg})$, HMW, MMW and LMW fractions of the CWE (53, 35 and $112 \mathrm{mg} / \mathrm{kg}$, respectively), HWE TM02 (200 mg/kg), ME TM02 (200 mg/kg), reference drug (indomethacin at $10 \mathrm{mg} / \mathrm{kg}$ ) or control group (6\% sodium bicarbonate in saline) was injected intraperitoneally into the rats $(2 \mathrm{ml} /$ $\mathrm{kg}$ for each rat). The dosages used for HMW, MMW and LMW fractions were calculated based on the fractionated yield of each fraction from $200 \mathrm{mg} / \mathrm{kg}$ of CWE. All extracts and the reference drug were prepared in $6 \%$ sodium bicarbonate in saline. Intraperitoneal injection was carried out one hour before the carrageenan treatment. Edema was induced by a sub-plantar injection of $1.5 \%$ carrageenan in saline $(0.2 \mathrm{ml})$ into the footpad of the right hind paw of all animals. The right hind paw volumes of these rats were measured using a plethysmometer (IITC INC., USA) at hourly intervals up to $5 \mathrm{~h}$. Paw edema volume was calculated by measuring paw volume increment: $\left(V_{t}-V_{0}\right) . V_{t}$ is the average volume of the right hind paw at each time interval after carrageenan injection while $V_{0}$ is the average volume of the right hind paw before carrageenan injection. The percentage inhibition of edema volume at each hour compared to the control group was calculated using the following formula:

$$
\text { Percentage inhibition }=[(A-B) / A] \times 100
$$

Where $\mathrm{A}=\left(\mathrm{V}_{\mathrm{t}}-\mathrm{V}_{0}\right)_{\text {control }} ; \mathrm{B}=\left(\mathrm{V}_{\mathrm{t}}-\mathrm{V}_{0}\right)_{\text {treatment }}$

The median inhibitory dose $\left(\mathrm{ID}_{50}\right)$ for the inhibition of inflammation at $3^{\text {rd }}$ and $4^{\text {th }} \mathrm{h}$ (peak edema) after inflammation induction was calculated.

\section{Cotton pellet induced granuloma study}

The inhibition effect of CWE on granuloma formation in rats was examined as described by Barua et al. [14]. The rats $(n=6 /$ group $)$ were anesthetised with ketamine $(45 \mathrm{mg} / \mathrm{kg})$ and xylazine $(4.5 \mathrm{mg} / \mathrm{kg}$ ) and shaved on their backs. An incision was made on the back followed by subcutaneously implantation of sterilised cotton pellets weighing $20 \pm 1 \mathrm{mg}$. The animals were fed orally with CWE at $200 \mathrm{mg} / \mathrm{kg}$ from day 1 to 7 . Control group received $6 \%$ sodium bicarbonate in saline at $10 \mathrm{ml} / \mathrm{kg}$. Indomethacin group $(1 \mathrm{mg} / \mathrm{kg})$ was fed orally every 2 days. On the $8^{\text {th }}$ day, the animals were euthanised using an overdose of carbon dioxide. The cotton pellets surrounded by granulomatous tissue were removed and made free from extraneous tissues. The wet pellets were weighed and dried at $60^{\circ} \mathrm{C}$ overnight to a constant weight. The mean dry weight of granulomatous tissue (after subtracting the weight of cotton pellet) was determined. The percentage inhibition was calculated by comparing the mean dry and wet weight of the treated group with the control group.

\section{Isolation of the protein and non-protein components (P-HMW and NP-HMW) of the HMW fraction}

The proteins of HMW fraction (P-HMW) were precipitated with ammonium sulphate, which was added gradually to the $\mathrm{HMW}$ fraction at $4^{\circ} \mathrm{C}$ until $100 \%$ saturation was reached. After stirring for $1 \mathrm{~h}$, the solution was centrifuged to collect the precipitated proteins. The supernatant was desalted by Sephadex G-50 (Sigma-Aldrich, USA) chromatography (column size $\mathrm{v}=228.3 \mathrm{ml}$ ) and eluted with $0.05 \mathrm{M}$ ammonium acetate buffer at $2 \mathrm{ml} /$ min. The fractions collected were then freeze-dried. The sample was termed non-protein component of the HMW fraction (NP-HMW). The protein pellet was dissolved in MiliQ water and desalted with Vivaspin 15R (5000 MWCO), and was termed protein component of the HMW fraction (P-HMW). The protein and carbohydrate contents of P-HMW and NP-HMW were determined by Bradford and phenol sulphuric acid method, respectively, as described earlier.

\section{Determination of the glucan content of the HMW fraction and its protein and non-protein components isolated by ammonium sulfate precipitation}

The glucan content of HMW fraction as well as its protein and non-protein components was determined by Mushroom and Yeast Glucan Assay Kit (Megazyme International Ireland Ltd, Bray Co, Wicklow, Ireland) according to manufacturer's instructions. Briefly, total glucan plus D-glucose in oligosaccharides, sucrose and free D-glucose were solubilised in concentrated hydrochloric acid (37\%) and hydrolysed by $1.3 \mathrm{M} \mathrm{HCl}$ at $100^{\circ}$ $\mathrm{C}$ for $2 \mathrm{~h}$. $2 \mathrm{M} \mathrm{KOH}$ was then added to neutralise the hydrolysates. Hydrolysis to D-glucose was completed by incubation with a mixture of highly purified exo-1,3- $\beta$ glucanase and $\beta$-glucosidase. The hydrolysates were then incubated with glucose oxidase/peroxidase mixture (GOPOD) reagent. Absorbance was measured at $510 \mathrm{~nm}$ against the GOPOD reagent blank and compared to D-glucose standard to calculate percentage of total glucan plus oligomers etc. Alpha glucan plus Dglucose in sucrose and free D-glucose was solubilised and hydrolysed in $2 \mathrm{M} \mathrm{KOH}$ and amyloglucosidase $(1630 \mathrm{U} / \mathrm{ml})$ plus invertase $(500 \mathrm{U} / \mathrm{mL})$. The hydrolysates were incubated with GOPOD reagent. Absorbance was measured at $510 \mathrm{~nm}$ against GOPOD reagent blank and compared to D-glucose standard to calculate percentage of alpha glucan plus oligomers etc. Percentage of beta glucan content was obtained by subtracting percentage of total glucan plus oligomers etc. and alpha glucan plus oligomers. 


\section{Cell culture for studies of inhibition of TNF alpha production}

The murine macrophage cell line RAW 264.7 (ATCC ${ }^{\oplus}$ TIB-71 $1^{\mathrm{rm}}$ ) was grown in DMEM (ATCC) supplemented with $10 \%$ heat inactivated $\mathrm{FBS}, 100 \mathrm{U} / \mathrm{mL}$ penicillin, and $100 \mu \mathrm{g} / \mathrm{mL}$ streptomycin, at $37^{\circ} \mathrm{C}$ in a humidified $5 \%$ $\mathrm{CO}_{2}$ incubator. To examine cell viability, the cells (seeded at $2 \times 10^{5}$ cells/well in 96-well plate) was pretreated with the respective extracts for $1 \mathrm{~h}$ and then stimulated with $0.10 \mu \mathrm{g} / \mathrm{ml}$ LPS for 24 hours. Medium was then removed and $100 \mu \mathrm{l}$ of $0.5 \mathrm{mg} / \mathrm{ml} \mathrm{MTT} \mathrm{was}$ added to each well and incubated for $1.5 \mathrm{~h}$ at $37^{\circ} \mathrm{C}$ in the dark. After removing the supernatant, $100 \mu \mathrm{l}$ DMSO was added to the cells to dissolve the formazan crystals. The absorbance of each group was measured by a microplate reader at $570 \mathrm{~nm}$. Absorbance of treatment groups was normalized to the LPS-treated control, and expressed as percentage viability.

\section{Measurement of inhibition of TNF-alpha production}

RAW 264.7 macrophages were cultured in 96-well plate with CWE, HMW, MMW, LMW and NP-HMW at 12.50, 25.00, 50.00, 75.00 and $100.00 \mu \mathrm{g} / \mathrm{ml}$, and P-HMW at $0.10,0.25,0.50,0.75,1.00,1.25,1.50,2.00$ and $2.50 \mu \mathrm{g} / \mathrm{ml}$ for $1 \mathrm{~h}$, and then incubated with $0.10 \mu \mathrm{g} / \mathrm{mL}$ LPS for $24 \mathrm{~h}$. Supernatants were obtained and frozen at $-80^{\circ} \mathrm{C}$ until analysis. TNF-alpha in the culture medium was determined by TNF- $\alpha$ mouse ELISA kit (Novex ${ }^{\odot}$ ) according to the manufacturer's recommended protocols. The ELISA plates were read using a microplate reader at $450 \mathrm{~nm}$. The result was expressed in percentage of inhibition of TNF-alpha production of the various treatment groups as compared to LPS stimulated group without pre-treatment, and $\mathrm{IC}_{50}$ values were then calculated.

\section{Statistical analysis}

All data were expressed as mean \pm S.E.M. and analysed using One-way Analysis of Variance (ANOVA). Statistical differences between the means of control and treatment groups were determined using Dunnett's $t$ (two-sided) test. In case of variance heterogeneity, Dunnett's T3 test was used. The homogeneity of variances was calculated using Levene statistics. Statistical differences between results on $200 \mathrm{mg} / \mathrm{kg}$ CWE TM02 and ME TM02 as well as HWE TM02 were analysed using Independent Samples t-test. Results were considered significant at $p<0.05$.

\section{Results}

Determination of total carbohydrate and protein content of the various sclerotial extracts

The carbohydrate content of CWE, HWE and ME were determined to be $68.4 \%, 92.2 \%$ and $12.8 \%$ by dry weight $(\mathrm{w} / \mathrm{w})$, respectively, and the protein content were found to be $2.0 \%, 0.2 \%$ and $0.2 \%$ by dry weight $(\mathrm{w} / \mathrm{w})$, respectively.

\section{Extraction Yield of CWE TM02, HWE TM02 and ME TM02}

The extraction yield of CWE, HWE and ME were 20\%, $37 \%$ and $5 \%$ by dry weight $(\mathrm{w} / \mathrm{w})$, respectively.

\section{Fractionation of CWE}

CWE was separated into HMW, MMW and LMW fractions by Sephadex G-50 gel filtration chromatography (Figure 1). The HMW fraction consisted of $4 \%$ protein and $79 \%$ carbohydrate by dry weight $(w / w)$. The MMW fraction consisted of $1 \%$ protein and $54 \%$ carbohydrate by dry weight $(\mathrm{w} / \mathrm{w})$, while the LMW fraction contained $0.3 \%$ of protein and $24 \%$ carbohydrate by dry weight $(\mathrm{w} / \mathrm{w})$.

\section{Carrageenan induced paw edema study}

CWE was found to reduce carrageenan induced paw edema in SD rats at all doses employed (25, 50, 100 and $200 \mathrm{mg} / \mathrm{kg}$ ) after $1-5 \mathrm{~h}$ of carrageenan injection (Table 1). CWE at 50, 100 and $200 \mathrm{mg} / \mathrm{kg}$ displayed significant inhibition of paw edema as compared to control group from $2^{\text {nd }}$ to $5^{\text {th }} \mathrm{h}$ post carrageenan injection $(\mathrm{p}<$ 0.05). A significant inhibition of paw edema formation was observed in the rat treated with CWE at $200 \mathrm{mg} / \mathrm{kg}$ at first hour post carrageenan injection. Paw edema inhibition in dose dependent manner was observed in rat treated with CWE at all doses employed after 2-5 h of carrageenan injection.

Paw edema of SD rat treated with CWE reached maximal size at $3^{\text {rd }}$ to $4^{\text {th }} \mathrm{h}$ post carrageenan injection. The median inhibitory doses $\left(\mathrm{ID}_{50}\right.$ ) of the CWE for the suppression of paw edema at the $3^{\text {rd }}$ and $4^{\text {th }} \mathrm{h}$ were both $88 \mathrm{mg} / \mathrm{kg}$. CWE at $200 \mathrm{mg} / \mathrm{kg}$ showed paw edema inhibition which was higher than inhibition caused by the standard drug indomethacin at $10 \mathrm{mg} / \mathrm{kg}$, after $1-5 \mathrm{~h}$ of carrageenan injection. HMW fraction of CWE $(53 \mathrm{mg} /$ $\mathrm{kg}$ ) showed inhibitory effect to paw edema formation in $\mathrm{SD}$ rats which was higher than MMW (35 mg/kg) and LMW $(112 \mathrm{mg} / \mathrm{kg})$ fractions of the same extract.

HWE and ME at $200 \mathrm{mg} / \mathrm{kg}$ displayed paw edema inhibitory activity which was significantly lower (Independent sample t-test, $p<0.05)$ than CWE at the same dosage (after $1-5 \mathrm{~h}$ of carrageenan injection), with $\mathrm{ME}$ TM02 being the least potent.

\section{Cotton pellet induced granuloma study}

CWE at $200 \mathrm{mg} / \mathrm{kg}$ did not significant cause suppression of the wet and dry weight of granuloma as compared to the control group (Table 2). However, the wet and dry weight of granuloma from rats treated with $1 \mathrm{mg} / \mathrm{kg}$ indomethacin for every 2 days were significantly reduced by $20.8 \%$ and $20.3 \%$, respectively. 


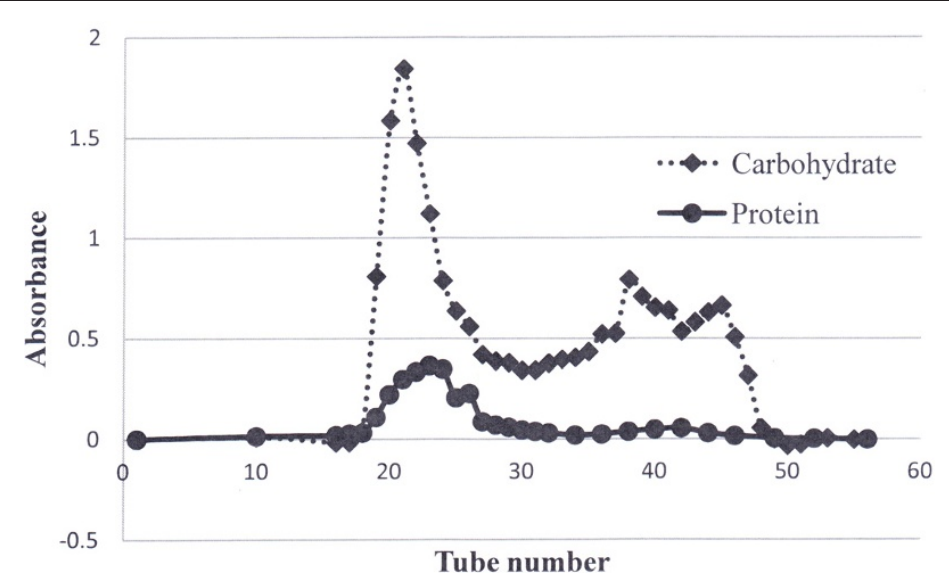

Figure 1 Sephadex G-50 superfine gel filtration chromatography of the cold water extract (CWE). The cold water extract (CWE, 500 mg dissolved in $5.6 \mathrm{ml}$ milliQ water) was loaded to the column $(v=112 \mathrm{ml})$ and $3 \mathrm{ml}$ per fraction were collected into each test tube.

\section{The protein and non-protein components of the HMW} fraction

The HMW fraction was subjected to $100 \%$ ammonium sulphate precipitation to yield the protein (P-HMW) and non-protein components (NP-HMW). The protein component consisted of protein and large amount of carbohydrate, with a carbohydrate to protein ratio of 8 . About $79.7 \%$ of the carbohydrate was alpha glucan and oligomers etc. and only $1.1 \%$ was beta glucan. On the other hand, the non-protein component (NP-HMW) was 99.3\% carbohydrate, of which $57.5 \%$ was alpha glucan and oligomers etc. and $3.2 \%$ was beta glucan.

\section{Inhibition of TNF-alpha production}

The CWE and its high and medium molecular weight fractions (HMW and MMW) all exhibited dose-dependent
TNF-alpha inhibition activity (Figure 2, in all experiments, cell viability $\geq 75 \%$ ). The half maximal inhibitory concentration $\left(\mathrm{IC}_{50}\right)$ of CWE, HMW and MMW was 32.0, 16.0 and $56.0 \mu \mathrm{g} / \mathrm{ml}$, respectively. The low molecular weight fraction did not exhibit the inhibitory activity. The protein component of the HMW exhibited very potent TNF alpha inhibition activity with $\mathrm{IC}_{50}$ of $0.76 \mu \mathrm{g}$ protein $/ \mathrm{ml}$ (data not shown), but the non-protein component did not exhibit any inhibitory activity.

\section{Discussion}

The medicinal mushroom $L$. rhinocerotis has been used extensively by the indigenous people from Peninsular Malaysia. Usually, the sclerotium of the mushroom is grated on a hard surface with some water, and the resulting aqueous mixture is further diluted with water and

Table 1 Effects of sclerotial extracts of $L$. rhinocerotis cultivar TM02 on carrageenan induced paw edema in rats

\begin{tabular}{ccccccc}
\hline Group & $\begin{array}{c}\text { Dose } \mathbf{( m g / k g} \\
\text { body weight) }\end{array}$ & \multicolumn{5}{c}{ Paw edema volume (ml) } \\
\cline { 3 - 7 } & $\mathbf{1}^{\text {st }}$ hour & $\mathbf{2}^{\text {nd }}$ hour & $\mathbf{3}^{\text {rd }}$ hour & $\mathbf{4}^{\text {th }}$ hour & $\mathbf{5}^{\text {th }}$ hour \\
\hline Control & & $0.28 \pm 0.02$ & $0.76 \pm 0.04$ & $0.85 \pm 0.03$ & $0.90 \pm 0.04$ & $0.86 \pm 0.04$ \\
CWE TM02 & $\mathbf{2 5}$ & $0.25 \pm 0.02(12)$ & $0.52 \pm 0.04^{*}(32)$ & $0.70 \pm 0.03(18)$ & $0.70 \pm 0.03^{*}(22)$ & $0.65 \pm 0.04^{*}(25)$ \\
& $\mathbf{5 0}$ & $0.18 \pm 0.02(36)$ & $0.40 \pm 0.07^{*}(48)$ & $0.50 \pm 0.06^{*}(42)$ & $0.51 \pm 0.05^{*}(44)$ & $0.46 \pm 0.05^{*}(47)$ \\
& $\mathbf{1 0 0}$ & $0.18 \pm 0.01(35)$ & $0.22 \pm 0.04^{*}(71)$ & $0.33 \pm 0.04^{*}(62)$ & $0.41 \pm 0.03^{*}(55)$ & $0.35 \pm 0.02^{*}(60)$ \\
& $\mathbf{2 0 0}$ & $0.11 \pm 0.03^{*}(61)$ & $0.13 \pm 0.03^{*}(83)$ & $0.10 \pm 0.03^{*}(88)$ & $0.11 \pm 0.03^{*}(88)$ & $0.10 \pm 0.03^{*}(89)$ \\
HMW & $\mathbf{5 3 * *}$ & $0.11 \pm 0.02^{*}(63)$ & $0.12 \pm 0.02^{*}(84)$ & $0.12 \pm 0.02^{*}(86)$ & $0.09 \pm 0.02^{*}(90)$ & $0.08 \pm 0.02^{*}(91)$ \\
MMW & $\mathbf{3 5 * *}$ & $0.16 \pm 0.03^{*}(44)$ & $0.30 \pm 0.04^{*}(61)$ & $0.35 \pm 0.05^{*}(65)$ & $0.51 \pm 0.05^{*}(43)$ & $0.44 \pm 0.03^{*}(49)$ \\
LMW & $\mathbf{1 1 2 * *}$ & $0.23 \pm 0.03(20)$ & $0.46 \pm 0.05^{*}(39)$ & $0.51 \pm 0.05^{*}(41)$ & $0.51 \pm 0.04^{*}(43)$ & $0.47 \pm 0.04^{*}(46)$ \\
ME TM02 & $\mathbf{2 0 0}$ & $0.24 \pm 0.05(15)$ & $0.68 \pm 0.04(11)$ & $0.78 \pm 0.04(9.0)$ & $0.73 \pm 0.04^{*}(19)$ & $0.69 \pm 0.03^{*}(20)$ \\
HWE TM02 & $\mathbf{2 0 0}$ & $0.20 \pm 0.03(31)$ & $0.41 \pm 0.06^{*}(46)$ & $0.50 \pm 0.05^{*}(42)$ & $0.49 \pm 0.04^{*}(46)$ & $0.47 \pm 0.03^{*}(45)$ \\
Indomethacin & $\mathbf{1 0}$ & $0.18 \pm 0.03(35)$ & $0.23 \pm 0.03^{*}(69)$ & $0.26 \pm 0.03^{*}(69)$ & $0.37 \pm 0.03^{*}(59)$ & $0.34 \pm 0.03^{*}(57)$ \\
\hline
\end{tabular}

Each value is mean \pm S.E.M of six rats. ${ }^{*} p<0.05$, compared with control using Dunnett's $t$ (two-sided) test. Values given in parentheses represent the percentage inhibition of edema volume at each hour as compared to the control group. ${ }^{* *}$ Amount isolated from $200 \mathrm{mg} / \mathrm{kg}$ of CWE TM02 using sephadex G-50 gel filtration chromatography. CWE-cold water extract; HWE-hot water extract; ME-methanol extract; HMW-high molecular weight fraction; MMW-medium molecular weight fraction; LMW-low molecular weight fraction. 
Table 2 Effect of the cold water extract (CWE) and indomethacin on cotton pellet induced granuloma in rats

\begin{tabular}{cccr}
\hline Treatment & $\begin{array}{c}\text { Dose } \\
(\mathbf{m g} / \mathbf{k g})\end{array}$ & \multicolumn{2}{c}{ Granulomatous tissue } \\
\cline { 3 - 4 } & - & Wet weight $(\mathbf{m g})$ & Dry weight $(\mathbf{m g})$ \\
\hline 6\% sodium bicarbonate (control) & 200 & $281.0 \pm 13.8$ & $39.6 \pm 1.4$ \\
CWE TM02 & 1 & $281.2 \pm 13.9$ & $40.2 \pm 2.4$ \\
Indomethacin & $222.7 \pm 14.3^{*}(20.8 \%)$ & $31.5 \pm 2.6^{*}(20.3 \%)$ \\
\hline
\end{tabular}

Values are mean \pm S.E.M. Values given in parentheses represent percentage of inhibition. *Significant difference with control (ANOVA, Dunnett's $t$ (two-sided) test, $p<0.05$ ).

consumed, with or without boiling $[5,15]$. These methods of preparation mimic cold and hot water extract and hence cold and hot water extractions were used in the study in the investigation of anti-inflammatory activity of the mushroom. The methanol extraction was used to investigate if the non-polar, water insoluble substances also contribute to the anti-inflammatory activity.

Carrageenan induced rat hind paw edema has been widely used for evaluation of anti-inflammatory drugs as the relative potency estimates obtained from most drugs tend to reflect clinical experience [16]. Inflammation induced by carrageenan is acute, well researched and highly reproducible [17]. The course of carrageenan induced paw edema consisted of three phases [18]. The first phase is mediated by histamine and serotonin during the first hour, after which the increased vascular permeability is maintained by kinin (secondary phase) release up to $2.5 \mathrm{~h}$ [18]. From 2.5-6.0 $\mathrm{h}$, the mediator appears to be a prostaglandin (final phase), release of which is closely associated with migration of leucocytes into the inflamed site [18].

The cold water extract exhibited anti-acute inflammatory activity by reducing paw edema induced by carrageenan at all the doses tested $(25,50,100$ and $200 \mathrm{mg} / \mathrm{kg})$, during all three phases of edema development. Significant paw edema inhibition in a dose dependent manner was observed in rats treated with CWE from $25-200 \mathrm{mg} / \mathrm{kg}$ $(p<0.05)$ at $2^{\text {nd }}-5^{\text {th }} \mathrm{h}$ post carrageenan injection. The anti-inflammatory pattern of CWE was similar to $10 \mathrm{mg} /$ $\mathrm{kg}$ of indomethacin (an NSAID) in which all three phases of edema development induced by carrageenan were also inhibited. The CWE at $200 \mathrm{mg} / \mathrm{kg}$ showed greater extent of paw edema inhibition than that of $10 \mathrm{mg} / \mathrm{kg}$ indomethacin during all three phases of edema development.

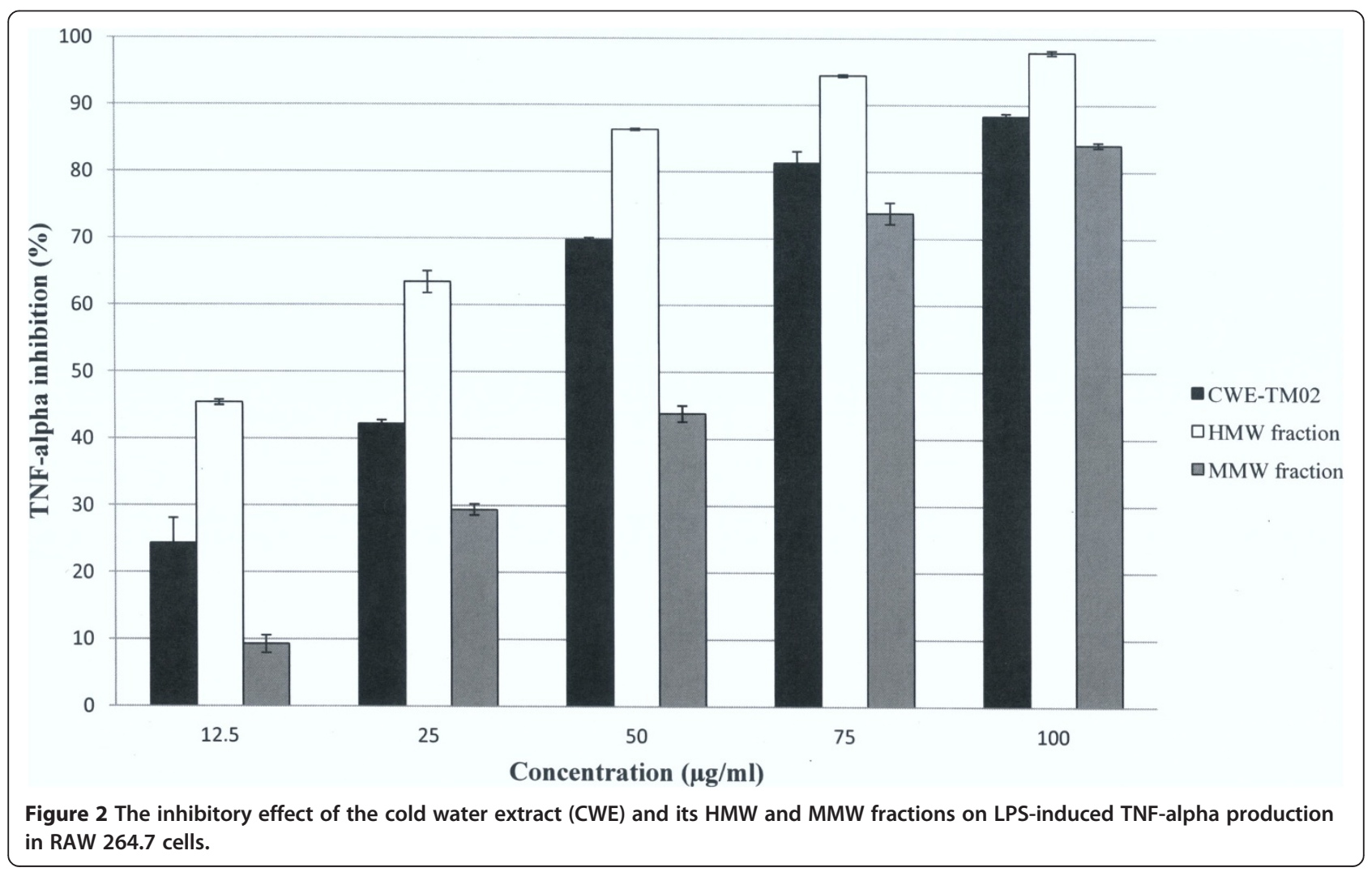


Lakshimi et al. [19] reported that ethanol extract of Ganoderma lucidum mycelium at $1000 \mathrm{mg} / \mathrm{kg}$ showed $65 \%$ paw edema inhibition after $3 \mathrm{~h}$ of carrageenan injection whereas CWE at lower dosage $(200 \mathrm{mg} / \mathrm{kg})$ gave $88 \%$ paw edema inhibition. Beta glucan rich extract from Caripia montagnei at $50 \mathrm{mg} / \mathrm{kg}$ significantly reduced the paw edema induced by carrageenan at $71 \%$ [20]. It should be noted, however, that the experimental design of the above mentioned findings (including ours) vary from one another and as such, it is not possible to make quantitative comparison.

In $200 \mathrm{mg} / \mathrm{kg}$ of cold water extract, the amount of the HMW, MMW and LMW fractions were $53 \mathrm{mg} / \mathrm{kg}, 35$ and $112 \mathrm{mg} / \mathrm{kg}$, respectively. Paw edema inhibition activity of the HMW fraction at $53 \mathrm{mg} / \mathrm{kg}$ dosage was comparable to that of $200 \mathrm{mg} / \mathrm{kg}$ CWE, whereas $35 \mathrm{mg} / \mathrm{kg}$ of MMW and $112 \mathrm{mg} / \mathrm{kg}$ of LMW fraction both showed substantially lower anti-inflammatory activity. This showed that the anti-inflammatory activity of CWE is mainly contributed by HMW fraction but the possibility of synergistic effect between HMW, MMW and LMW fractions cannot be excluded. CWE also exhibited in vitro anti-inflammatory activity as shown by its inhibitory effect on TNF alpha production in LPS-inducedmacrophages, and both its HMW and MMW fractions exhibited strong inhibitory activity.

The nature of the active principle in the CWE causing anti-inflammatory activity has yet to be elucidated. A possible candidate is the polysaccharides-protein complexes or polysaccharides found in the extract. It has been reported that the anti-inflammatory properties of Phellinus rhinosus (Berk) and Poria cocos cultured mycelia were attributed to the polysaccharide-protein complex and watersoluble polysaccharide, respectively [21,22]. The HMW fraction consists of $4 \%$ protein and $79 \%$ carbohydrates. The protein component isolated by ammonium sulfate precipitation, exhibited very potent TNF alpha inhibitory activity but the nature of the bioactive protein(s) that exhibit the anti-inflammatory activity in the protein component are yet to be elucidated. Since the protein component contained large amount of carbohydrate $(8$ parts of carbohydrate to 1 part of protein, mostly alpha glucan), the polysaccharide-protein complex may play a role in the anti-inflammatory effect. On the other hand, the non-protein component that was essentially carbohydrate (and mainly alpha glucan, with only $3.2 \%$ beta glucan) did not inhibit TNF-alpha production and hence was devoid of anti-inflammatory activity.

The hot water extract (HWE) and methanol extract (ME) at the dosage of $200 \mathrm{mg} / \mathrm{kg}$ were far less effective in reducing paw edema induced by carrageenan in all three phases of edema development when compared to CWE, at the same dosage. The extraction yield of CWE, HWE and ME were 20\% (w/w), 37\% (w/w) and 5\% (w/w), respectively. The major anti-inflammatory principle(s) of the sclerotial powder of L. rhinocerotis cultivar TM02 are in the cold water extract, in particular, its high molecular weight fraction (HMW). The HWE exhibited weaker antiinflammatory activity but because of its high yield it also contains substantial amount of anti-inflammatory principle. The yield of ME was so low that it contains only negligible amount of the bioactive substance.

Granulomatous inflammation is a focal chronic inflammatory response to tissue injury evoked by a poorly soluble substance characterised by the accumulation and proliferation of leukocytes, principally of the mononuclear type [23]. Cotton pellet induced granuloma test is widely used to assess transudative, exudative and proliferative phase of inflammation [24]. In this study, CWE at $200 \mathrm{mg} / \mathrm{kg}$ did not show reduction of wet and dry weight of implanted cotton pellet, indicating that it might not inhibit the transudative and proliferative phase of chronic inflammation.

\section{Conclusion}

All three extracts of the sclerotial powder of L. rhinocerotis cultivar TM02 possess anti acute-inflammatory effect but most of the bioactive substance(s) appear to be extractable by cold water. The anti-inflammatory activity of the cold water extract (CWE) is mainly contributed by its high molecular weight (HMW) fraction, in particular its protein component, which was very potent in the inhibition of TNF-alpha production with an $\mathrm{IC}_{50}$ of $0.76 \mu \mathrm{g} / \mathrm{ml}$. However, the possibility of synergistic effect between HMW, MMW and LMW fractions cannot be excluded. Cold water extract at $200 \mathrm{mg} / \mathrm{kg}$ did not inhibit transudative and proliferative phase of chronic inflammation.

\section{Abbreviations \\ CWE: Cold water extract; HWE: Hot water extract; ME: Methanol extract; HMW: High molecular weight fraction; MMW: Medium molecular weight fraction; LMW: Low molecular weight fraction; LPS: Lipopolysaccharide.}

\section{Competing interests}

The authors declare that they have no competing interests.

\section{Authors' contributions}

SSL carried out all the experiments and drafted the manuscript. NHT, SYF and SMS supervised the works and edited the manuscript. CST and STN cultivated and supplied sclerotia of L. rhinocerotis cultivar TM02. All authors read and approved the final manuscript.

\section{Acknowledgments}

This work was financially supported by University Malaya Research Grant (UMRG): RG076/12BIO, Post Graduate Research Grant (PPP) PV054-2011B from University of Malaya and Fundamental Research Grant Scheme (FRGS): FP029-2014A from Ministry of Science, Technology and Innovation, Malaysia.

\section{Author details}

'Department of Molecular Medicine, Faculty of Medicine, University of Malaya, 50603 Kuala Lumpur, Malaysia. ${ }^{2}$ Department of Pharmacology, Faculty of Medicine, University of Malaya, 50603 Kuala Lumpur, Malaysia. ${ }^{3}$ Biotechnology Research Centre, MARDI, P.O.Box 12301, 50744 Kuala Lumpur, 
Malaysia. ${ }^{4}$ Ligno Biotech Sdn Bhd, Taman Perindustrian Balakong Jaya 2, Selangor 43300 Balakong Jaya, Malaysia.

Received: 8 November 2013 Accepted: 22 September 2014 Published: 25 September 2014

\section{References}

1. Mothana RAA: Anti-inflammatory, antinociceptive and antioxidant activities of the endemic Soqotraen Boswellia elongata Balf. f. and Jatropha unicostata Balf. f. in different experimental models. Food Chem Toxicol 2011, 49:2594-2599.

2. Sherwood ER, Toliver-Kinsky T: Mechanisms of the inflammatory response. Best Pract Res Clin Anaesthesiol 2004, 18:385-405.

3. Laine L: Approaches to nonsteroidal anti-inflammatory drug use in the high-risk patient. Gastroenterology 2001, 120:594-606.

4. Raskin JB: Gastrointestinal effects of nonsteroidal anti-inflammatory therapy. Am J Med 1999, 106(5B):3S-12S.

5. Chang YS, Lee SS: Utilisation of macrofungi species in Malaysia. Fungal Divers 2004, 15:15-22.

6. Lee SS, Chang YS, Noraswati MNR: Utilization of macrofungi by some indigenous communities for food and medicine in Peninsular Malaysia. For Ecol Manage 2009, 257:2062-2065.

7. Wong KH, Cheung PCK: Sclerotia: emerging functional food derived from mushrooms. In Mushrooms as Functional Foods. Edited by Cheung PCK. Hoboken, New Jersey: John Wiley and Sons, Inc; 2008:111-146.

8. Tan CS: Setting-up pilot-plant for up-scaling production of Tiger-Milk'-mushroom as dietary functional food. Government of Malaysia: MOA TF0109M004; 2009:9.

9. Tan CS, Ng ST, Vikineswary S, Lo EP, Tee CS: Genetic markers for identification of a Malaysian medicinal mushroom Lignosus rhinocerus (Cendawan susu rimau). Acta Hort (ISHS) 2010, 859:161-167.

10. Bradford MM: A rapid and sensitive method for the quantitation of microgram quantities of protein utilizing the principle of protein-dye binding. Anal Biochem 1976, 72:248-254.

11. Dubois M, Gilles KA, Hamilton JK, Rebers PA, Smith F: Colorimetric method for determination of sugars and related substances. Anal Chem 1956, 28(3):350-356.

12. Howard-Jones NA: A CIOMS ethical code for animal experimentation. WHO Chron 1985, 39(1):51-56.

13. Arawwawala M, Thabrew I, Arambewela L, Handunnetti S: Anti inflammatory activity of Trichosanthes cucumerina Linn. in rats. J Ethnopharmacol 2010, 131:538-543.

14. Barua CC, Pal SK, Roy JD, Buragohain B, Talukdar A, Barua AG, Borah P: Studies on the anti-inflammatory properties of Plantago erosa leaf extract in rodents. J Ethnopharmacol 2011, 134:62-66.

15. Chan GG: Tiger's milk fungus. The Malayan Forester 1953, 2(2):103.

16. Babu NP, Pandikumar P, Ignacimuthu S: Anti-inflammatory activity of Albizia lebbeck Benth., an ethnomedicinal plant, in acute and chronic animal models of inflammation. J Ethnopharmacol 2009, 125:356-360.

17. Morris CJ: Carrageenan-induced paw edema in the rat and mouse. In Inflammation Protocols. Edited by Winyard PG, Wiloughby DA. Totowa, New Jersey: Humana Press Inc; 2003:115-121.

18. Di Rosa M, Willoughby DA: Screens for anti-inflammatory drugs. J Pharm Pharmacol 1971, 23(4):297-298.

19. Lakshmi B, Ajith TA, Sheena N, Gunapalan N, Janardhanan KK: Antiperoxidative, anti-inflammatory, and antimutagenic activities of ethanol extract of mycelium of Ganoderma lucidum occuring in South India. Teratog Carcinog Mutagen 2003, 1:85-97.

20. Queiroz LS, Nascimento MS, Cruz AKM, Castro AJG, Moura MFV, Baseia IG, Araújo RM, Benevides NMB, Lima LFA, Leite EL: Glucans from the Caripia montagnei mushroom present anti-inflammatory activity. Int Immunopharmacol 2010, 10:34-42.

21. Janardhanan KK, Meera CR, Nitha B, Vishwakarma RA: Anti-inflammatory and free radical scavenging activities of polysaccharide-protein complex isolated from Phellinus rimosus (Berk.) Pilát (Aphyllophoromycetideae). Int J Med Mushrooms 2009, 11(4):365-373.
22. Lu MK, Cheng JJ, Lin CY, Chang CC: Purification, structural elucidation, and anti-inflammatory effect of a water-soluble 1,6-branched 1,3-a-dgalactan from cultured mycelia of Poria cocos. Food Chem 2010, 118(2):349-356.

23. Hirsh BC, Johnson WC: Concepts of granulomatous inflammation (review). Int J Dermatol 1984, 23(2):90-100

24. Swingle KF, Shideman FE: Phases of the inflammatory response to subcutaneous implantation of a cotton pellet and their modification by certain anti-inflammatory agents. J Pharmacol Exp Ther 1972, 183(1):226-234.

\section{doi:10.1186/1472-6882-14-359}

Cite this article as: Lee et al: Anti-inflammatory effect of the sclerotium of Lignosus rhinocerotis (Cooke) Ryvarden, the Tiger Milk mushroom. BMC Complementary and Alternative Medicine 2014 14:359.

\section{Submit your next manuscript to BioMed Central and take full advantage of:}

- Convenient online submission

- Thorough peer review

- No space constraints or color figure charges

- Immediate publication on acceptance

- Inclusion in PubMed, CAS, Scopus and Google Scholar

- Research which is freely available for redistribution

Submit your manuscript at www.biomedcentral.com/submit
() Biomed Central 